\title{
Effect of Severe Plastic Deformation on the Mechanical and Electrical Properties of Cr-modified Cu-Ni-Si Alloys
}

\author{
Cagatay Elibol ${ }^{1^{*}}$

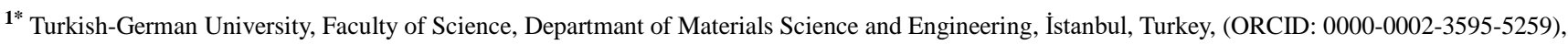 \\ elibol@tau.edu.tr
}

(First received 10 September 2021 and in final form 30 November 2021)

(DOI: 10.31590/ejosat.1004910)

ATIF/REFERENCE: Elibol, C. (2021). Effect of Severe Plastic Deformation on the Mechanical and Electrical Properties of Crmodified Cu-Ni-Si Alloys. European Journal of Science and Technology, (27), 866-872.

\begin{abstract}
Copper alloys are widely used in automotive, electronics, petrochemical and nuclear applications due to their good mechanical/ corrosion resistance and conductivity. Although mostly beryllium containing copper alloys are utilized in these industries due to their superior properties. However, due to the toxic effects of beryllium, there is a need for alternative copper alloys. Among the alternative alloys, $\mathrm{Cu}-\mathrm{Ni}-\mathrm{Si}$ alloys known as Corson alloys are commonly preferred. Both alloying and thermomechanical treatments play important roles to attain similar or better properties in this alloy system, compared to the beryllium containing $\mathrm{Cu}$ alloys. In this research, a combined thermomechanical treatment is performed in order to characterize the effect of severe plastic deformation and subsequent heat treatments (i.e., precipitation hardening) on strength, hardness and electrical conductivity of Corson alloys modified by Chromium. The copper alloys having different chemical compositions (Cr contents) are processed using equal-channel angular pressing (ECAP) after solution annealing and quenching. The behavior of Cr-modified alloys is characterized in detail and the effect of the combined thermomechanical treatment and of the $\mathrm{Cr}$ content on the final mechanical and physical behavior is discussed. The results show that during aging of solution treated alloys containing $0.4,0.6$ and $0.8 \mathrm{wt}-\% \mathrm{Cr}$, a significant increase in both hardness and electrical conductivity is observed, and that increasing $\mathrm{Cr}$ content also leads to an increase of both properties. After processing by two-pass ECAP, the hardness of all investigated alloys is significantly increased compared with the solution treated state, whereas the electrical conductivity is adversely affected by severe plastic deformation. The mechanical behavior of the ECAPed alloys can be enhanced even further by performing post-ECAP aging. Therefore, it allows us to develop Cu-Ni-Si alloys by severe plastic deformation process, as an alternative to commonly used beryllium containing copper alloys. The preliminary results provide new insights for the development of construction materials that can be used in the electronic industry, high-speed rail systems, aerospace applications and nuclear power plants, which are recently high priority topics.
\end{abstract}

Keywords: Copper alloys, Severe plastic deformation (SPD), Equal channel angular pressing (ECAP), Mechanical and electrical properties, Precipitation (age) hardening

\section{Cr Modifiyeli Cu-Ni-Si Alaşımlarının Mekanik ve Elektriksel Özellikleri Üzerine Așırı Plastik Deformasyon Etkisi}

$\ddot{O} z$

Bakır alaşımları, sahip oldukları yüksek mukavemet, korozyon direnci ve iletkenlikleri nedeniyle otomotiv, elektronik, petrokimya ve nükleer uygulamalarında yaygın olarak kullanılmaktadır. Bu endüstrilerde üstün özelliklerinden dolayı çoğunlukla berilyum içeren bakır alaşımları kullanılmakla birlikte, berilyumun toksik etkileri nedeniyle alternatif bakır alaşımlarına ihtiyaç duyulmaktadır. Bunlar arasında Corson alaşımları olarak bilinen $\mathrm{Cu}-\mathrm{Ni}-\mathrm{Si}$ alaşımları yaygın olarak tercih edilmektedir. Hem alaşımlama hem de termomekanik işlemler, bu alaşım sisteminde berilyum içeren $\mathrm{Cu}$ alaşımlarına kıyasla benzer ve hatta daha iyi özellikler elde etme

* Corresponding Author: elibol@tau.edu.tr 
noktasında önemli rol oynamaktadır. Bu araştırmada, aşırı plastik deformasyon ve akabinde gerçekleştirilen isıl işlemlerin (çökelme sertleşmesi) $\mathrm{Cr}$ ile modifiye edilmiş $\mathrm{Cu}-\mathrm{Ni}$-Si alaşımlarının mukavemeti, sertliği ve elektrik iletkenliği üzerine etkisini karakterize etmek için kombine termomekanik işlem uygulanmıştır. Farklı kimyasal bileşime (Cr içeriğine) sahip bakır alaşımları, çözeltiye alma ve su verme işleminden sonra eş kanallı açısal pres (EKAP) yöntemi kullanılarak şekillendirilmiştir. $\mathrm{Cr}$ modifiyeli alaşımların davranışı ayrıntılı olarak karakterize edilmiş ve kombine termomekanik işlem ile alaşımdaki $\mathrm{Cr}$ içeriğinin nihai mekanik ve fiziksel özellikler üzerine etkisi irdelenmiştir. Elde edilen sonuçlar, ağırlıkça \%0,4, 0,6 ve $0,8 \mathrm{Cr}$ içeren çözeltiye alınmış alaşımların yaşlandırılması sırasında hem sertlikte hem de elektriksel iletkenlikte önemli bir artış gözlendiğini ve artan $\mathrm{Cr}$ içeriğinin $\mathrm{Cu}-\mathrm{Ni}$ - $\mathrm{Si}$ alaşımının sertliğini ve iletkenliğini artırdığını göstermektedir. İki paso EKAP ile işlemi neticesinde, incelenen tüm alaşımların sertliği çözeltiye alınmış duruma kıyasla önemli ölçüde artarken, elektriksel iletkenliği aşırı plastik deformasyondan negatif etkilenmiştir. EKAPlanmış alaşımlarının mekanik özellikleri, EKAP sonrası yaşlandırma ile daha da geliştirilebilmektedir. Bu nedenle, yaygın olarak kullanılan bakır-berilyum alaşımlarına alternatif $\mathrm{Cu}-\mathrm{Ni}$-Si alaşımlarının aşırı plastik deformasyon ile geliştirilmesi mümkündür. İlk sonuçlar, son zamanların yüksek öncelikli alanları arasında yer alan elektronik endüstrisi, yüksek hız raylı sistemler, uzay/havacılık uygulamaları ile nükleer santrallerde kullanılabilecek yapı malzemelerinin geliştirilmesine ışık tutmaktadır.

Anahtar Kelimeler: Bakır alaşımları, Aşırı plastik deformasyon, Eş kanallı açısal pres, Mekanik ve elektriksel özellikler, Çökelme sertleşmesi

\section{Introduction}

Copper and its alloys are used in many different industries such as electronics, automotive and nuclear industries. The range of applications of $\mathrm{Cu}$ alloys is extended due to their good strength, wear and corrosion resistance, and high electrical conductivity (Lei et al., 2013a; Lockyer and Noble, 1994). Most of these alloys are generally precipitation hardened and are alloyed with alloying elements (with very low solubility) such as $\mathrm{Cr}$ to maintain high electrical conductivity. $\mathrm{Cu}-\mathrm{Be}, \mathrm{Cu}-\mathrm{Co}-\mathrm{Ni}$ $\mathrm{Be}, \mathrm{Cu}-\mathrm{Cr}-\mathrm{Zr}$ and $\mathrm{Cu}-\mathrm{Ni}-\mathrm{Si}$ alloy families belong to the group of precipitation hardenable copper alloys (Monzen and Watanabe, 2008; Woodcraft et al., 2001; Xie et al., 2009). Various studies on these alloys have been performed to optimize hardness and conductivity as a function of different alloying and heat treatment processes (Xiao, 2020). Although Be containing $\mathrm{Cu}$ alloys with their high strength and conductivity are among the precipitation hardenable copper alloys, the toxicity of beryllium and its low stress relaxation at high temperatures require the development of new alloy systems instead of these alloys (Lei et al., 2013a; Lei et al., 2013b).

Zhao et al. (2003) characterized the aging behavior of $\mathrm{Cu}$ Ni-Si alloys. Furthermore, Watanabe et al. (2018) and Li et al. (2009) investigated the deformation behavior of a $\mathrm{Cu}-\mathrm{Ni}-\mathrm{Si}$ alloy processed by high-pressure torsion (HPT) and the microstructural evolution of alloys modified by $\mathrm{Sn}$ and $\mathrm{Mg}$, respectively. The microstructure and properties of a highstrength $\mathrm{Cu}-\mathrm{Ni}-\mathrm{Si}$ alloy developed with addition of $\mathrm{Co}$ and $\mathrm{Cr}$ were analyzed by Krishna et al. (2013). They have reported that aging of the solution treated samples leads to a significant increase in strength and electrical conductivity which is mainly attributed to the formation of precipitates. The contribution of thermomechanical processes, alloying and $\mathrm{Ni}: \mathrm{Si}$ ratio to the improvement of the alloy properties is remarkable. The hardness values of the modified $\mathrm{Cu}-\mathrm{Ni}-\mathrm{Si}$ alloys processed by conventional thermomechanical treatments (rolling, forging, etc.) with subsequent aging are given in Figure $1 \mathrm{a}$. $\mathrm{Cu}-\mathrm{Ni}-\mathrm{Si}$ alloys can reach hardness values ranging from 190 to $350 \mathrm{HV}$ as a function of both composition and thermomechanical processes. Moreover, high hardness values can only be achieved with high $\mathrm{Ni}: \mathrm{Si}$ ratios and alloying. The modification and thermomechanical processes would lead to superior mechanical beahvior of $\mathrm{Cu}-\mathrm{Ni}-\mathrm{Si}$ alloys compared to $\mathrm{Be}$ containing $\mathrm{Cu}$ alloys. The change in electrical conductivity levels of these alloys is given in Figure 1b. Although high Ni:Si ratios provide high strength of the alloys, the electrical conductivity can be significantly reduced with increasing Ni:Si ratio. However, the electrical conductivity values (25-50 IACS \%) of the modified and thermomechanically treated $\mathrm{Cu}-\mathrm{Ni}-\mathrm{Si}$ alloys are higher than the conductivity value of the $\mathrm{Cu}-\mathrm{Be}$ alloys (22 IACS \%). Considering both Figures 1a and b, it becomes clear that there is a need for new processes to further enhance the mechanical properties of copper alloys, although it is seen that modified alloys exhibit superior mechanical properties if conventional thermomechanical processes are diversified.

(a)

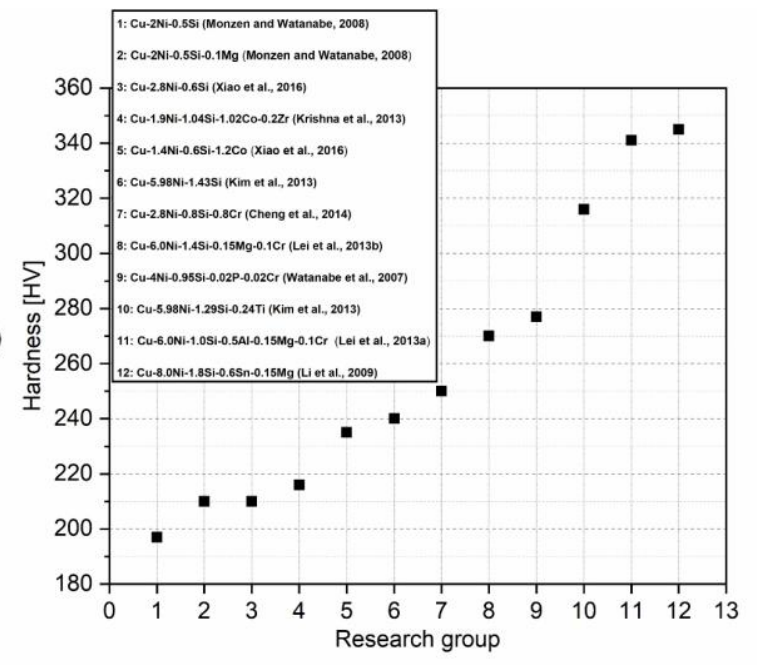

(b)

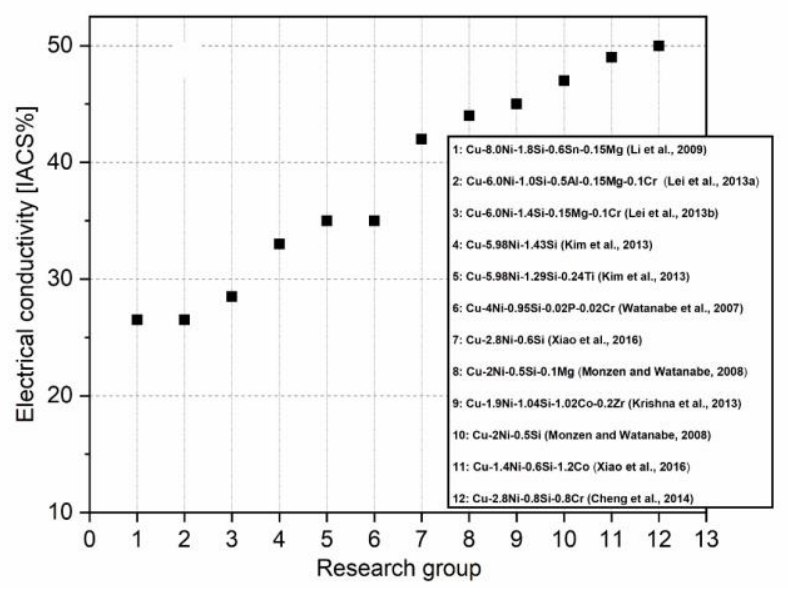

Figure 1. (a) Hardness and (b) electrical conductivity values of modified/processed (by conventional thermomechanical treatments) $\mathrm{Cu}$ - $\mathrm{Ni}$-Si alloys investigated by different research groups 
Various severe plastic deformation (SPD) methods, particularly equal-channel angular pressing (ECAP) and HPT with subsequent aging processes are used to enhance the mechanical and physical behavior of the alloys due to the grain refinement during SPD process and due to the precipitation hardening during subsequent aging (Valiev et al., 2002; Valiev and Langdon, 2006). Among the SPD techniques, ECAP is widely used to produce ultrafine-grained materials having excellent properties (Valiev and Langdon, 2006; Furukawa et al., 2001; Furuno et al., 2004). Khereddine et al. (2013) have been working on the ECAP processing of $\mathrm{Cu}-\mathrm{Ni}-\mathrm{Si}$ alloys. They processed $\mathrm{Cu}-2.5 \mathrm{Ni}-0.6 \mathrm{Si}$ alloys with a constant $\mathrm{Ni}$ :Si ratio of 5:1 by ECAP and HPT and reported on the change of mechanical properties after SPD. They concluded that the hardness increases with increasing number of torsion revolutions and reaches the highest value of $285 \mathrm{HV}$ after 10 revolutions, whereas the mean grain size and dislocation density of the alloy are equal to $38 \mathrm{~nm}$ and $7.59 \times 10^{15} \mathrm{~m}^{-2}$, respectively. In the alloy processed by ECAP after 12 passes, the highest hardness value $(195 \mathrm{HV})$ is reached and the mean grain size and the dislocation density are equal to $44 \mathrm{~nm}$ and $4.91 \times 10^{15} \mathrm{~m}^{-2}$, respectively. As can be clearly seen, ultrafine-grained structures and increasing the dislocation density in the matrix achieved by SPD processes provide a significant improvement of the properties of this alloy system. In this work, the effect of ECAP process and precipitation hardening during subsequent aging as well as of the $\mathrm{Cr}$ addition/content on the mechanical and physical behavior of $\mathrm{Cu}$ $\mathrm{Ni}-\mathrm{Si}$ alloys having different $\mathrm{Cr}$ contents is investigated systematically.

\section{Material and Method}

In this work, the effect of ECAP process and precipitation hardening on the mechanical and electrical properties of $\mathrm{Cu}-\mathrm{Ni}$ $\mathrm{Si}$ alloys modified by $\mathrm{Cr}$ was investigated. The chemical compositions of the investigated alloys are shown in Table 1. $\mathrm{Ni}$ :Si ratio in all investigated alloys is constant $(\sim 2: 1)$ and the content of $\mathrm{Cr}$ alloying element is equal to $0.4,0.6$ and 0.8 .

Table 1. Chemical compositions of the Cu alloys investigated in this study

\begin{tabular}{c|c|c|c|c}
\hline Alloy & $\mathbf{C u}$ & $\mathbf{N i}$ & $\mathbf{S i}$ & $\mathbf{C r}$ \\
\hline $\begin{array}{c}\text { CuNiSi- } \\
\mathrm{Cr}\end{array}$ & 98.2 & 0.25 & 0.107 & 0.4 \\
\hline $\begin{array}{c}\text { CuNiSi- } \\
\mathrm{Cr}\end{array}$ & 99 & 0.035 & 0.015 & 0.6 \\
\hline $\begin{array}{c}\mathrm{CuNiSi}- \\
\mathrm{Cr}\end{array}$ & 98.8 & 0.04 & 0.026 & 0.82 \\
\hline
\end{tabular}

The solution annealing with subsequent quenching and aging, ECAP processing and post-ECAP aging at $450{ }^{\circ} \mathrm{C}$ for 2 , 4, 6 and $8 \mathrm{~h}$ were performed (s. Figure 2 ) and after each step, the mechanical and electrical properties were characterized by the quasi-static, uniaxial tensile tests $\left(\dot{\varepsilon} \sim 10^{-3} \mathrm{~s}^{-1}\right)$, the hardness and electrical conductivity measurements with regard to the effect of the combined thermomechanical treatment (i.e., ECAP + postECAP aging / precipitation hardening) and the $\mathrm{Cr}$ content on the alloy properties.

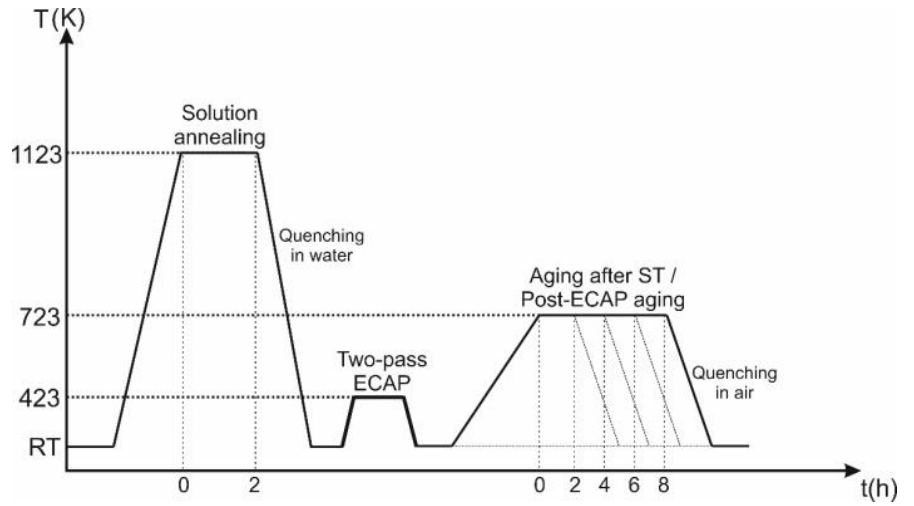

Figure 2. Procedure of the conventional heat treatment vs. combined thermomechanical treatment of the investigated $\mathrm{Cu}$ alloys

Two-pass ECAP processing of the investigated $\mathrm{Cu}$ alloys were performed at $423 \mathrm{~K}$ using a die with a channel/corner angle of $90^{\circ} / 0^{\circ}$ via route $\mathrm{Bc}\left(90^{\circ}\right.$ counterclockwise rotation between passes) (s. Figure 3). During ECAP processing, the pressing speed of hydraulic press with 120 tons capacity was set to 20 $\mathrm{mm} \cdot \mathrm{min}^{-1}$.

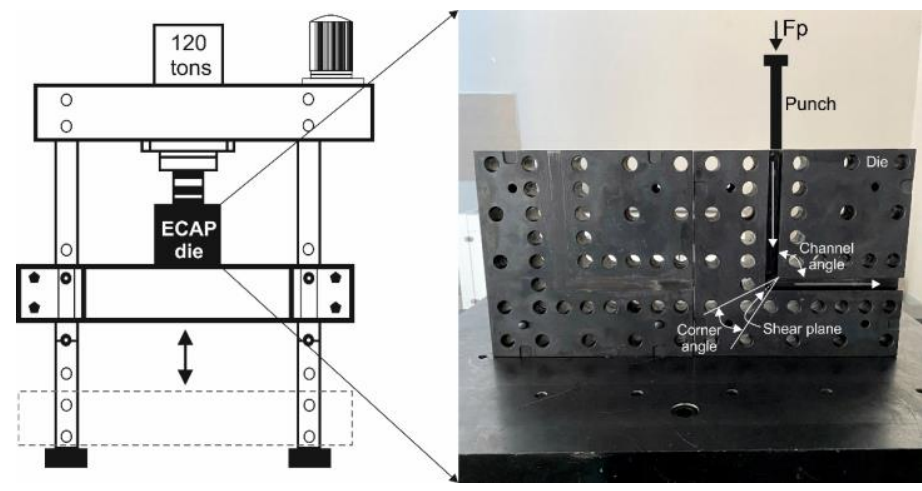

Figure 3. Hydraulic press and ECAP die with the channel angle of $90^{\circ}$ and corner angle of $0^{\circ}$ used in this study

Tensile tests were performed using a universal testing machine (Schimadzu AGX-V $100 \mathrm{kN}$ ) at room temperature under quasi-static loading conditions $\left(\dot{\varepsilon} \sim 10^{-3} \mathrm{~s}^{-1}\right)$. The microhardness measurements (with a load of $0.5 \mathrm{~kg}$ and dwell time of $20 \mathrm{~s}$ ) were conducted using a Vickers microhardness tester (Microbul 1000 DN-AT). Electrical conductivity of $\mathrm{Cu}$ alloys was measured using an eddy current electrical conductivity meter (AutoSigma 3000DL). Samples for tensile tests, hardness and electrical conductivity measurements were cut from the center of the non-ECAPed and ECAPed billets along the longitudinal (ECAP) direction (s. Figure 4).

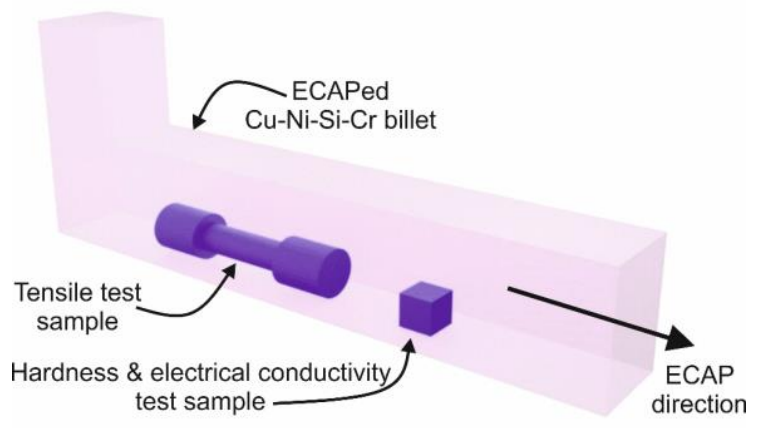

Figure 4. Schematic illustration of the cutting direction of samples for the characterization 


\section{Results and Discussion}

In Figure 5a and b, the measured hardness and electrical conductivity values of the $\mathrm{Cu}-\mathrm{Ni}-\mathrm{Si}-\mathrm{Cr}$ alloys processed by conventional heat treatment (solution treatment (ST) + aging) and by combined thermomechanical treatment $(\mathrm{ST}+\mathrm{ECAP}+$ post-ECAP aging) are plotted as a function of aging time and $\mathrm{Cr}$ content. During aging at $723 \mathrm{~K}$, the hardness of both ST and ECAPed alloys increase with increasing aging time due to precipitation with a homogeneous distribution (Cheng et al., 2014). The precipitation formation leads to decreasing solute content in the matrix and decreasing electrical resistivity (reciprocal of electrical conductivity) (Lei et al., 2017; Ahn et al., 2020). Therefore, increasing aging time (i.e., increasing volume fraction of precipitates) results in increasing conductivity in all investigated state. In early phase of aging, the increase in conductivity is more pronounced due to the faster precipitation. Furthermore, both the hardness and conductivity of the investigated alloys increase with increasing $\mathrm{Cr}$ content. The highest value of the electrical conductivity ( 50 IACS\%) is reached in the alloy with $0.8 \% \mathrm{Cr}$ after processing by conventional heat treatment. ECAP processing results in decreasing electrical conductivity of all investigated alloy groups with different $\mathrm{Cr}$ contents due to the increasing resistivity (increased electrons scattering) by severe plastic deformation (Arenas et al., 2015), whereas the hardness of ECAPed alloys is significantly higher compared with ST alloys due to the increased number of grain boundaries of the material processed by ECAP. The hardness and electrical conductivity values measured as a function of different investigated states and $\mathrm{Cr}$ contents are listed in Table 2.

(a)

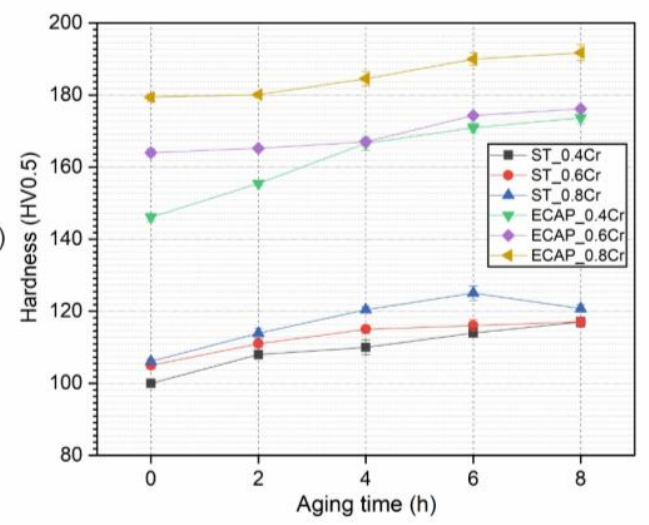

(b)

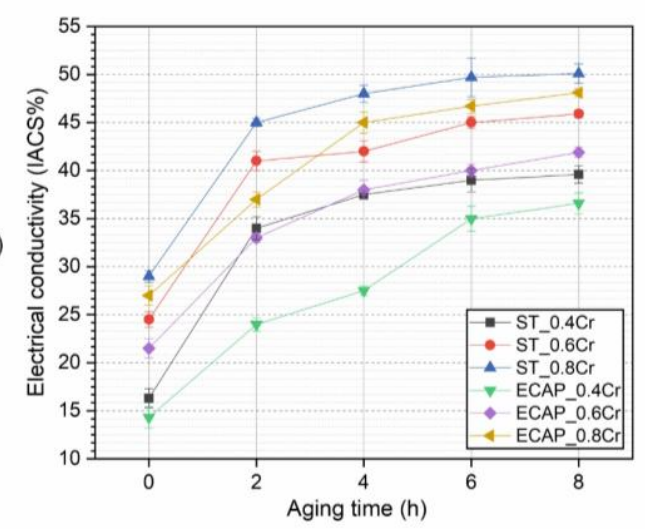

Figure 5. (a) Hardness and (b) electrical conductivity values of the solution treated (ST) and ECAPed $\mathrm{Cu}$-Ni-Si alloys modified by 0.4, 0.6 and $0.8 \% \mathrm{Cr}$ as a function of aging time at $723 \mathrm{~K}$
Table 2. Hardness and electrical conductivity values of $\mathrm{Cu}-\mathrm{Ni}$ $\mathrm{Si}$-Cr alloys for different states and $\mathrm{Cr}$ contents investigated in this study

\begin{tabular}{c|c|c|c|c}
\hline \multirow{2}{*}{$\begin{array}{c}\text { Investigated } \\
\text { state }\end{array}$} & $\begin{array}{c}\mathbf{C r} \\
\text { content } \\
(\%)\end{array}$ & $\begin{array}{c}\text { ECAPed } \\
\text { + Peak } \\
\text { aged (6 h) }\end{array}$ & $\begin{array}{c}\text { ST + } \\
\text { Peak } \\
\text { aged } \\
(\mathbf{6} \text { h) }\end{array}$ & ST \\
\hline \multirow{2}{*}{$\begin{array}{c}\text { Hardness } \\
\text { (HV0.5) }\end{array}$} & $\mathbf{0 . 8}$ & 190 & 126 & 108 \\
\cline { 2 - 5 } & $\mathbf{0 . 6}$ & 174 & 116 & 106 \\
\cline { 2 - 5 } & $\mathbf{0 . 4}$ & 170 & 114 & 100 \\
\hline \multirow{2}{*}{$\begin{array}{c}\text { Electrical } \\
\text { conductivity }\end{array}$} & $\mathbf{0 . 8}$ & 46.5 & 50 & 27.5 \\
\cline { 2 - 5 } (IACS\%) & $\mathbf{0 . 6}$ & 40 & 45 & 24 \\
\cline { 2 - 5 } & $\mathbf{0 . 4}$ & 35 & 39 & 16 \\
\hline
\end{tabular}

Figure 6 shows the engineering stress-strain curves for solution treated (ST), peak aged (PA at $723 \mathrm{~K}$ for $6 \mathrm{~h}$ ) and ECAPed samples with different $\mathrm{Cr}$ contents under uniaxial tensile loading at room temperature and a $\dot{\varepsilon} \sim 10^{-3} \mathrm{~s}^{-1}$. The ultimate strains and tensile strengths obtained from mechanical responses are listed in Table 3 . Two-pass $90^{\circ}$ ECAP processing results in a considerable increase of tensile strength of all investigated alloys compared to the ST samples due to the grain refinement by ECAP according to the Hall-Petch relation (Petch, 1953) and due to the increasing dislocation density by strain hardening. $\mathrm{Cu}-\mathrm{Ni}-\mathrm{Si}$ alloy with $0.8 \% \mathrm{Cr}$ exhibits the highest tensile strength of $\sim 360 \mathrm{MPa}, \sim 570 \mathrm{MPa}$ and $\sim 40 \mathrm{MPa}$ in ST, PA and ECAPed states, respectively. After processing by two-pass ECAP, only one tensile test specimen could be cut from the ECAPed billet. However, it is well-known that the postECAP peak aging should lead to a higher tensile strength than that of $570 \mathrm{MPa}$ in PA state due to the subsequent additional precipitation hardening (as can also be seen in the hardness plots in Figure 5a based on the general relation between strength and hardness). In multi-pass ECAPed alloys, it is expected that plastic deformation mainly occurs by twinning instead of dislocation slip due to the high dislocation density which strongly hinders the dislocation motion. The twinning mechanism has a similar effect on the strengthening of the materials as the grain refinement. ECAP processing results in higher tensile strengths of $\mathrm{Cu}-\mathrm{Ni}-\mathrm{Si}$ alloys with $0.6 \%$ and $0.4 \%$ $\mathrm{Cr}$ compared with that after solution treatment followed by peak aging. The mechanical properties can be improved even further by post-ECAP aging. 
(a)

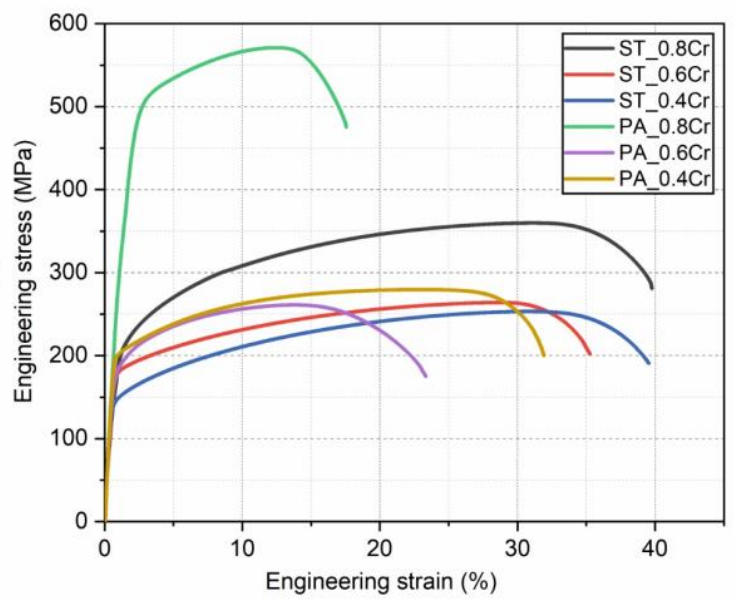

(b)

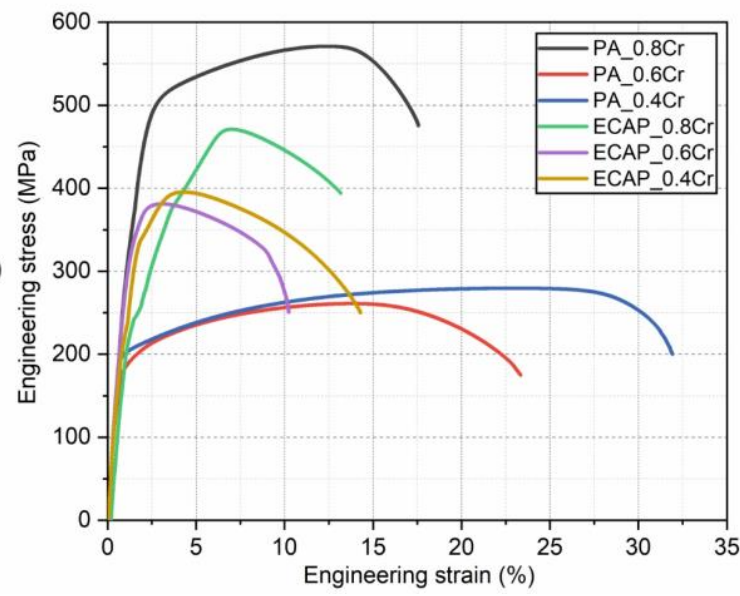

Figure 6. Engineering stress-strain curves of $\mathrm{Cu}$-Ni-Si-Cralloys with different $\mathrm{Cr}$ contents for (a) ST and PA states and (b) PA and ECAPed state

It is noteworthy that the ultimate strain (i.e., the ductility) and the uniform elongation of the $\mathrm{Cu}-\mathrm{Ni}-\mathrm{Si}-\mathrm{Cr}$ alloys are strongly decreased by ECAP processing (s. Table 3). This is attributed to the early-stage strain (deformation) localization and subsequent early-stage fracture that may occur in fine grained metals processed by severe plastic deformation due to the prevention of the formation and accumulation of new dislocations by means of the microstructural characteristics such as high/critical dislocation density, substructures formed in elongated grains, and high internal stresses (Frint and Wagner, 2004; Ma et al., 2009).

\section{Conclusions and Recommendations}

In this study, the effect of ECAP and $\mathrm{Cr}$ content on the mechanical and electrical properties of precipitation hardening $\mathrm{Cu}-\mathrm{Ni}-\mathrm{Si}$ alloys was systematically characterized by subjecting the alloys to both the conventional heat treatment and the combined thermomechanical treatment. The results are summarized below:

- The hardness of $\mathrm{Cu}-\mathrm{Ni}-\mathrm{Si}-\mathrm{Cr}$ alloys increases with increasing $\mathrm{Cr}$ content (in the investigated range of 0.4 to 0.8 ): After solution treatment, the hardness values of the alloys with $0.8 \% \mathrm{Cr}, 0.6 \% \mathrm{Cr}$ and $0.4 \% \mathrm{Cr}$ content are equal to 108,106 and 100 HV0.5, respectively. Furthermore, two-pass ECAP processing results in a significant increase of hardness for all investigated alloy compositions: After aging of the alloys with $0.8 \% \mathrm{Cr}, 0.6 \% \mathrm{Cr}$ and $0.4 \% \mathrm{Cr}$ content at $723 \mathrm{~K}$ for $6 \mathrm{~h}$, an increase of $\sim 51 \%, \sim 50 \%$ and $\sim 49 \%$ occurs, respectively. This is attributed to the mechanisms of strain hardening and grain refinement by ECAP processing, and of precipitation hardening by aging.

- An increase in the $\mathrm{Cr}$ content leads to increasing conductivity of the $\mathrm{Cu}-\mathrm{Ni}-\mathrm{Si}-\mathrm{Cr}$ alloys, whereas ECAP processing results in a significant decrease of electrical conductivity (i.e., increase of resistivity) due to the increased probability of electrons scattering by severe plastic deformation. The conductivity increases during aging at $723 \mathrm{~K}$ with increasing aging time due to the decreasing solute content in the matrix caused by the formation of precipitates.

- After processing of the $\mathrm{Cu}$ alloys investigated in this study by ECAP, due to the strain hardening and grain refinement, the yield (and tensile) strength is increased significantly, whereas the ductility of the ECAPed alloys is decreased considerably due to the localization of the deformation during the ECAP process, which may lead to an early-stage strain localization during post-ECAP plastic deformation.

Further investigations on $\mathrm{Cu}-\mathrm{Ni}$-Si alloys with different $\mathrm{Ni}$ :Si ratios and $\mathrm{Cr}$ contents should be performed by ECAP processing, and new strategies should be developed to solve the problems that may occur in the processing of modified alloys, especially in the case of high Ni:Si ratios. Thus, a matrix of $\mathrm{Cu}-$ $\mathrm{Ni}-\mathrm{Si}$ alloys that exhibits high strength and electrical conductivity after severe plastic deformation can be designed with varying the $\mathrm{Ni}: \mathrm{Si}$ ratio and content of the alloying elements.

\section{Acknowledge}

The author gratefully acknowledges the financial support of the Scientific Research Projects Unit of Turkish-German University (project number: 2019BF0004). 
Table 3. Ultimate strain and tensile strength values of $\mathrm{Cu}$-Ni-Si-Cr alloys for different states and Cr contents investigated in this study

\begin{tabular}{c|c|c|c|c|c|c|c|c|c}
\hline $\begin{array}{c}\text { Investigated } \\
\text { state }\end{array}$ & \multicolumn{2}{|c|}{ Solution treated (ST) } & \multicolumn{3}{c|}{ Peak aged (PA) } & \multicolumn{3}{c}{ ECAPed } \\
\hline $\begin{array}{c}\text { Cr content } \\
(\%)\end{array}$ & $\mathbf{0 . 4}$ & $\mathbf{0 . 6}$ & $\mathbf{0 . 8}$ & $\mathbf{0 . 4}$ & $\mathbf{0 . 6}$ & $\mathbf{0 . 8}$ & $\mathbf{0 . 4}$ & $\mathbf{0 . 6}$ & $\mathbf{0 . 8}$ \\
\hline $\begin{array}{c}\text { Tensile } \\
\text { strength } \\
(\mathbf{M P a})\end{array}$ & 250 & 255 & 360 & 270 & 265 & 570 & 390 & 383 & 470 \\
\hline $\begin{array}{c}\text { Ultimate } \\
\text { strain (\%) }\end{array}$ & 39 & 35 & 40 & 32 & 23 & 17.5 & 14 & 9 & 14 \\
\hline
\end{tabular}

\section{References}

Lei, Q., Li, Z., Xiao, T., Pang, Y., Xiang, Z.Q., Qiu, W.T., \& Xiao, Z. (2013a). A new ultrahigh strength $\mathrm{Cu}-\mathrm{Ni}-\mathrm{Si}$ alloy. Intermetallics, 42, 77-84.

https://doi.org/10.1016/j.intermet.2013.05.013

Lockyer, S.A., \& Noble, F.W. (1994). Precipitate structure in a Cu-Ni-Si alloy. J. Mater. Sci., 29, 218-226. https://doi.org/10.1007/BF00356596

Monzen, R., \& Watanabe, C. (2008). Microstructure and mechanical properties of $\mathrm{Cu}-\mathrm{Ni}-\mathrm{Si}$ alloys. Mater. Sci. Eng. A, 483-484, 117-119. https://doi.org/10.1016/j.msea.2006.12.163

Woodcraft, A., Sudiwala, R., \& Bhatia, R. (2001). The thermal conductivity of C17510 beryllium-copper alloy below 1 K. Cryogenics, 41, 603-606. https://doi.org/10.1016/S0011-2275(01)00127-8

Xie, H., Jia, L., \& Lu, Z. (2009). Microstructure and solidification behavior of $\mathrm{Cu}-\mathrm{Ni}-\mathrm{Si}$ alloys. Materials Characterization, 60, 114-118. https://doi.org/10.1016/j.matchar.2008.07.008

Xiao, T., Sheng, X.-F., Lei, Q., Zhu, J.-L., Li, S.Y., Liu, Z.R., \& Zhou, L. (2020). Effect of Magnesium on Microstructure Refinements and Properties Enhancements in High-Strength CuNiSi Alloys. Acta Metall. Sin., 33, (2020) 375-384. https://doi.org/10.1007/s40195-01900953-9

Lei, Q., Li, Z., Dai, C., Wang, J., Chen, X., Xie, J.M., Yang, W.W., \& Chen, D.L. (2013b). Effect of aluminum on microstructure and property of $\mathrm{Cu}-\mathrm{Ni}-\mathrm{Si}$ alloys, Mater. Sci. Eng. A, 572, 65-74. https://doi.org/10.1016/j.msea.2013.02.024

Zhao, D., Dong, Q.M., Liu, P., Kang, B.X., Huang, J.L., \& Jin, Z.H. (2003). Aging behavior of Cu-Ni-Si alloy. Mater. Sci. Eng. A, 361, 93-99. https://doi.org/10.1016/S09215093(03)00496-9

Watanabe, H., Kunimine, T., Watanabe, C., Monzen, R., \& Todaka, Y. (2018). Tensile deformation characteristics of a $\mathrm{Cu}-\mathrm{Ni}-\mathrm{Si}$ alloy containing trace elements processed by high-pressure torsion with subsequent aging. Mater. Sci. Eng. A, 730, 10-15. https://doi.org/10.1016/i.msea.2018.05.090

Li, Z., Pan, Z.Y., Zhao, Y.Y., Xiao, Z., \& Wang, M.P. (2009). Microstructure and properties of high-conductivity, superhigh-strength $\mathrm{Cu}-8.0 \mathrm{Ni}-1.8 \mathrm{Si}-0.6 \mathrm{Sn}-0.15 \mathrm{Mg}$ alloy. $J$. Mater. Res., 24, 2123-2129. https://doi.org/10.1557/jmr.2009.0251

e-ISSN: 2148-2683
Krishna, S.C., Srinath, J., Jha, A.K., Pant, B., Sharma, S.C., \& George, K.M. (2013). Microstructure and properties of a high-strength $\mathrm{Cu}-\mathrm{Ni}-\mathrm{Si}-\mathrm{Co}-\mathrm{Zr}$ alloy. J. Mater. Eng. Perform., 22, 2115-2120. https://doi.org/10.1007/s11665013-0482-6

Valiev, R.Z., Alexandrov, I.V., Zhu, Y.T., \& Lowe, T.C. (2002). Paradox of Strength and Ductility in Metals Processed by Severe Plastic Deformation. J. Mater. Res., 17, 5-8. https://doi.org/10.1557/jmr.2002.0002

Valiev, R.Z., \& Langdon, T.G. (2006). Principles of equalchannel angular pressing as a processing tool for grain refinement. Progress in Materials Science, 51, 881-981. https://doi.org/10.1016/j.pmatsci.2006.02.003

Furukawa, M., Horita, Z., Nemoto, M., \& Langdon, T.G. (2001). Processing of metals by equal-channel angular pressing. J. Mater. Sci., 36, 2835-2843. https://doi.org/10.1023/A:1017932417043

Furuno, K., Akamatsu, H., Oh-ishi, K., Furukawa, M., Horita, Z., \& Langdon, T.G. (2004). Microstructural development in equal-channel angular pressing using a $60^{\circ}$ die. Acta Mater., 52, 2497-2507.

https://doi.org/10.1016/j.actamat.2004.01.040

Khereddine, A.Y., Larbi, F.H., Kawasaki, M., Baudin, T., Bradai, D., \& Langdon, T.G. (2013). An examination of microstructural evolution in a $\mathrm{Cu}-\mathrm{Ni}-\mathrm{Si}$ alloy processed by HPT and ECAP. Materials Science and Engineering A, 576, 149-155. https://doi.org/10.1016/j.msea.2013.04.004

Xiao, X.P., Yi, Z.Y., Chen, T.T., Liu, R.Q., \& Wang, H. (2016). Suppressing spinodal decomposition by adding Co into $\mathrm{Cu}-\mathrm{Ni}-\mathrm{Si}$ alloy. Journal of Alloys and Compounds, 660, 178-183. https://doi.org/10.1016/j.jallcom.2015.11.103

Kim, H.G., Lee, T.W., Kim, S.M., Han, S.Z., Euh, K., Kim, W.Y., \& Lim, S.H. (2013). Effects of Ti Addition and Heat Treatments on Mechanical and Electrical Properties of Cu-Ni-Si Alloys. Met. Mater. Int., 19, 61-65. https://doi.org/10.1007/s12540-013-1011-8

Cheng, J.Y., Tang, B.B., Yu, F.X., \& Shen, B. (2014). Evaluation of nanoscaled precipitates in a $\mathrm{Cu}-\mathrm{Ni}-\mathrm{Si}-\mathrm{Cr}$ alloy during aging. Journal of Alloys and Compounds, 614, 189-195.

https://doi.org/10.1016/j.jallcom.2014.06.089 
Watanabe, C., Nishijima, F., Monzen, R., \& Tazaki, K. (2007). Mechanical Properties of $\mathrm{Cu}-4.0 \mathrm{wt} \% \mathrm{Ni}-0.95 \mathrm{wt} \% \mathrm{Si}$ Alloys with and without $\mathrm{P}$ and $\mathrm{Cr}$ Addition. Materials Science Forum, 561-565, 2321-2324. https://doi.org/10.4028/www.scientific.net/MSF.561565.2321

Lei, Q., Xiao, Z., Hu, W., Derby, B., \& Li, Z. (2017). Phase transformation behaviors and properties of a high strength Cu-Ni-Si alloy. Mater. Sci. Eng. A, 697, 37-47. https://doi.org/10.1016/j.msea.2017.05.001

Ahn, J.H., Han, S.Z., Choi, E.-A., Lee, H., Lim, S.H., Lee, J., Kim, K., Hwang, N.M., \& Han, H.N. (2020). The effect of bimodal structure with nanofibers and normal precipitates on the mechanical and electrical properties of $\mathrm{Cu}-\mathrm{Ni}-\mathrm{Si}$ alloy. Materials Characterization, 170, 110642. https://doi.org/10.1016/j.matchar.2020.110642

Arenas, C., Henriquez, R., Moraga, L., Munoz, E., \& Muno, R.C. (2015). The effect of electron scattering from disordered grain boundaries on the resistivity of metallic nanostructures. Applied Surface Science, 329, 184-196. https://doi.org/10.1016/j.apsusc.2014.12.045

Petch, N.J. (1953). The Cleavage Strengh of Polycrystals. The Journal of the Iron and Steel Institute, 174, 25-28.

Frint, P., \& Wagner, M.F.-X. (2019). Strain partitioning by recurrent shear localization during equal-channel angular pressing of an AA6060 aluminum alloy. Acta Mater., 176, 306-317. https://doi.org/10.1016/j.actamat.2019.07.009

Ma, A., Jiang, J., Saito, N., Shigematsu, I., Yuan, Y., Yang, D., \& Nishida, Y. (2009). Improving both strength and ductility of a $\mathrm{Mg}$ alloy through a large number of ECAP passes. Mater. Sci. Eng. A, 513-514, 122-127.

https://doi.org/10.1016/j.msea.2009.01.040 